\title{
Screening of a Soil Bacteria Collection for the Production of Alkali Thermostable Xylanases
}

\author{
C. R. Sampaio ${ }^{1}$, C. G. S. Silva ${ }^{2}$, E. C. T. Anjos ${ }^{3}$, R. P. M. Fernandes ${ }^{2} \&$ M. F. Fernandes ${ }^{3}$ \\ ${ }^{1}$ Colégio de Aplicação, Universidade Federal de Sergipe, São Cristóvão, Brazil \\ ${ }^{2}$ Departamento de Fisiologia, Universidade Federal de Sergipe, São Cristóvão, Brazil \\ ${ }^{3}$ Embrapa Tabuleiros Costeiros, Aracaju, Brazil \\ Correspondence: Roberta Fernandes, Departamento de Fisiologia, Universidade Federal de Sergipe, Av. \\ Marcehal Rondon S/N, São Cristóvão, Sergipe, 490137-000, Brazil. Tel: 55-79-3194-6843. E-mail: \\ robertafernandes@ufs.br
}

Received: March 14, 2018

Accepted: May 25, 2018 Online Published: July 15, 2018

doi:10.5539/jas.v10n8p232

URL: https://doi.org/10.5539/jas.v10n8p232

\begin{abstract}
This work aimed to evaluate a collection of common and rare soil bacteria regarding to extracellular xylanases production and to characterize the stability in contrasting conditions of temperature and $\mathrm{pH}$ of these enzymes. This collection consists of 120 isolates belonging to six phyla that were subjected to screening for xylanase activity in pure cultures and in the extracellular proteic extract (EPE). The ratio between the halos diameters of xylan hydrolysis and in the colonies on solid medium (ratio $\mathrm{H}: \mathrm{C}$ ) was used for the evaluation of cultures as selection criteria. EPEs of isolates with highest ratios $\mathrm{H}: \mathrm{C}$ were evaluated for the specific xylanases activity at $50{ }^{\circ} \mathrm{C}$ for $1 \mathrm{~h}$. EPE of the three isolates with the highest potential for activity under this condition were evaluated for optimum activity, stability at $60{ }^{\circ} \mathrm{C}$ and different $\mathrm{pH}$ values. Twenty-two isolates showed xylanase activity under these conditions. Xylanases from TC21 and TC119 showed high relative activity at temperatures up to $70{ }^{\circ} \mathrm{C}$ and were less sensitive to changes in $\mathrm{pH}$. Soil bacteria show high potential as a source of extracellular xylanases adapted to extreme $\mathrm{pH}$ and temperature conditions, which are required in agroindustrial processes.
\end{abstract}

Keywords: kraft pulp bleaching, microbial diversity, saccharification, non-culturable viable, thermostable enzymes

\section{Introduction}

Despite the importance of microorganisms in the maintenance of the biosphere, it is difficult to estimate the number of organisms in microbial communities due to their great genetic diversity (Haegeman et al., 2013), and just over 7,000 bacterial species have been described (Achtman \& Wagner, 2008). It is known that more than $99 \%$ of the bacteria from environmental samples remain uncultivated and most of these microorganisms found in the soil are insufficiently studied because of the rarity of their isolation in cultivation studies (Pham \& Kim, 2012).

The expected scientific benefits of greater knowledge about microbial diversity are related to the discovery of potentially exploitable microorganisms for the most diverse biotechnological processes, such as the production of enzymes for industrial and technological applications. Among the microorganisms that are not well explored are those belonging to the soil microbiota, which have immense biotechnological potential since they produce several enzymes that have been commercially exploited over the years (Jayani, Shivalika, \& Gupta, 2005).

There are about 200 enzymes produced by microorganisms available on the market from the 4000 enzyme types that are known at the moment, yet just 20 of these are produced in large quantities ( $\mathrm{Li}, \mathrm{X}$. Yang, S. Yang, Zhu, \& Wang, 2012). Regarding the global market for industrial enzymes, in 2014 this was around $\$ 4.2$ billion and is expected to reach $\$ 6.2$ billion from 2015 to 2020, with an annual growth rate (CAGR) of 7\% (BCC Research, 2014). Therefore, due to the high price of microbial enzymes, technology for improving their quality is developing each day (Gurung, Ray, Bose, \& Rai, 2013).

Brazil has imported most of its enzymes, although it has enormous potential for producing them. This potential is shown by the great biological diversity, still little explored, that could be the source of new organisms which produce enzymes of industrial interest, and the abundance of organic matter in the form of agricultural residues, 
such as rice straw or bagasse, which constitutes low-cost substrate for fermentation (Bon, Ferrara, \& Corvo, 2008).

Xylanases are among the most widely used industrial enzymes on the market (Cowan, 1996; Li et al., 2012b) and represent $20 \%$ of the global enzyme market together with cellulases and pectinases. Xylanases are produced by various organisms and most of the bacteria and fungi secrete these enzymes in the extracellular medium where they will act on hemicellulose material to release xylose as a directly assimilable final product. Among the bacteria, Actinobacteria and Firmicutes of the Bacillaceae family are reported to be the main producers of industrially important enzymes involved in lignocellulose degradation (Nagar, Mittal, Kumar, \& Gupta, 2012).

In several industrial applications, such as the bleaching stage of the kraft pulping process in paper production, the inlet pulp has a high temperature and alkaline $\mathrm{pH}$, making it necessary to search for alkali thermostable xylanases (Sharma \& Bajaj, 2005). In addition, cellulose-free xylanase is crucial to avoid degradation of the cellulose fibers (Techapun, Poosaram, \& Watanabe, 2003). These enzymes promote the removal of xylan, facilitating the leaching of lignin (Niehaus, Bertoldo, Kahler, \& Antranikian, 1999). Therefore, in the paper industry, the use of xylanases represents an important technological improvement because they promote an increase in the bleaching effect without chemical reagents and also decrease the production of pollutants during these processes (Walia, Guleria, Mehta, Chauhan, \& Parkash, 2017).

Another outstanding industrial process that makes use of enzymes is the production of second generation ethanol, where xylanases are used in the degradation of lignocellulosic biomass. Bioconversion of biomass, such as sugarcane bagasse and straw, has been widely studied for the purpose of producing biofuel from a renewable source, representing an important alternative for increasing second-generation ethanol production (Canilha et al., 2012). It is recognized that a large amount of sugar bagasse is inappropriately used, contributing to environmental (Schettino \& Holanda, 2015). As both bagasse and sugarcane straw are lignocellulose materials, they could be better utilized for biofuel generation, which would contribute even more to Brazil's leadership in the sugar-alcohol sector.

Bacterial xylanases are known to be stable at alkaline $\mathrm{pH}$ and high temperature and have faster growth than fungi propterties that are suitable for industrial requirements (Chakdar et al., 2016). Thus, the characterization of the enzymes is a crucial step to understanding their properties of optimal activity and stability at different values of $\mathrm{pH}$ and temperature, which enables an evaluation of their potential application in these different processes (Kashyap, Vohra, Chopra, \& Tewari, 2001). Several of these processes are performed using the cells themselves as a source of enzymes, but efficiency of the processes can be increased through the use of isolated and purified enzymes (Mohana, Shah, Divecha, \& Madamwar, 2008).

Considering the importance of xylanases in diverse agro-industrial uses, the present study involved evaluating a soil bacteria collection with the objective of selecting which produce alkaline thermostable extracellular xylanases.

\section{Method}

\subsection{Isolates and Growth Media}

A total of 120 bacterial isolates obtained from the Soil Microbiology Laboratory of Embrapa Tabuleiros Costeiros (Aracaju-SE) were evaluated for in vitro xylanolytic activity. The isolates were obtained from soil samples collected in a secondary forest or in cultivated land planted with maize and pigeon pea and were cultured using VL55 culture media (Sait, Hugenholtz, \& Janssen, 2002) with xylan as the sole source of carbon and nutrient agar in the original concentration or as a 10-fold, 100-fold and 1000-fold dilution. The taxonomic affiliation of the isolates was based on 16S rRNA gene partial sequencing. The 16S rRNA gene partial sequences obtained were compared with the sequences of bacteria of culture type deposited in the GenBank database (http://www.ncbi.nlm.nih.gov/) using the BLASTN software (Cavalcante, 2012).

The isolates were stored at $-20{ }^{\circ} \mathrm{C}$ in $50 \%$ glycerol, reactivated in liquid culture media of the same composition to the media used in the isolation and incubated $\left(32^{\circ} \mathrm{C}\right)$ in the dark until initial media turbidity. Thereafter, the reactivated cultures were inoculated in Petri dishes containing the solid media to verify purity.

\subsection{Selection of Extracellular Xylanase Producers in Solid Media}

To select the xylanase-producing bacteria, the isolates were inoculated into 50-mL Erlenmeyer flasks containing $20 \mathrm{~mL}$ of mineral saline solution (MSS) containing xylan as the sole carbon source (Bajaj \& Singh, 2010). The MSS solution is composed of $1 \% \mathrm{NH}_{4} \mathrm{NO}_{3}, 0.5 \% \mathrm{KH}_{2} \mathrm{PO}_{4}, 0.1 \% \mathrm{MgSO}_{4} \cdot 7 \mathrm{H}_{2} \mathrm{O}, 0.01 \% \mathrm{CaCl}_{2} \cdot 2 \mathrm{H}_{2} \mathrm{O}, 0.01 \%$ $\mathrm{NaCl}$ and $0.01 \% \mathrm{MnSO}_{4} \cdot \mathrm{H}_{2} \mathrm{O}$, with the addition of $0.5 \%$ xylan. Once the isolates were at the beginning of the exponential phase, indicated by initial turbidity of the medium, xylanase production tests were carried out on 
solid MSS medium containing xylan as the sole carbon source $(0.5 \%)$. For this, a $2-\mathrm{mL}$ volume of the liquid culture was centrifuged (14000 rpm for $5 \mathrm{~min})$ and washed twice with saline $(0.85 \% \mathrm{NaCl}, \mathrm{w} / \mathrm{v})$. Thereafter, the optical densities (OD) of the cell suspensions were adjusted to 0.7 in a spectrophotometer using wavelength of $500 \mathrm{~nm}$ to give $1 \times 10^{6} \mathrm{UFC} / \mathrm{mL}$. A $10-\mu \mathrm{L}$ aliquot was deposited in the center of each Petri dish containing MSS solidified with agar (2\%) or gellan (1\%). Triplicate plates were used for each isolate. Plates were incubated in the dark at $30{ }^{\circ} \mathrm{C}\left( \pm 2{ }^{\circ} \mathrm{C}\right)$ for seven days, and for an additional seven days if colony formation did not occur in the first period. Isolates whose colonies were not visible within 14 days were excluded from further procedures. Xylanase in vitro activity was evaluated by measuring the diameter of pale halos observed in the culture media, which are formed by xylan hydrolytic enzymes excreted by the colony and diffuse through the solid medium. To increase the contrast between the pale zone of the halo and the medium with xylan, $0.1 \%$ Congo red was added to the surface of the medium (Sharma \& Bajaj, 2005). Two perpendicular measurements were made for each halo. These measurements were taken on the day of the test with Congo red and seven days after the test. The diameter of the colonies was also measured on the same evaluation dates. Selection of the isolates with the highest activity was performed using the relationship between the diameters of the activity halos and the colonies ( $\mathrm{H}: \mathrm{C}$ ratio) considering both evaluation dates.

To test the hypothesis that the methods used in the isolation of bacteria (Cavalcante, 2012) result in cultures with different xylanase activities, the effect of various aspects of bacterial isolation on the $\mathrm{H}: \mathrm{C}$ ratios of the isolates was evaluated as described below. The t-test $(p<0.05)$ was used to compare the mean values of isolates obtained from different soils (agriculture versus forestry), solidifying agents in the culture medium (agar versus gellan), dilution of the inoculum used in plating $\left(10^{-6}\right.$ versus $\left.10^{-7}\right)$ and pour-plate versus spread-plate methods. The Bonferroni procedure $(\mathrm{p}<0.05)$ was used to compare the mean $\mathrm{H}: \mathrm{C}$ ratios of the isolates with different incubation durations until colony appearance and among the culture media. The t-test was also used to test the hypothesis that was a difference in xylanase activity between the bacteria in the collection classified as rare and common isolate.

\subsection{Preparation of Extracellular Protein Extracts (EPE)}

The isolates with higher $\mathrm{H}: \mathrm{C}$ ratios were selected and grown in the MSS medium with xylan $(0.5 \%)$ and incubated at $32{ }^{\circ} \mathrm{C} / 150 \mathrm{RPM}$ until the initial media turbidity was observed. This medium was filtered on a Millipore nitrocellulose filter $\left(0.22-\mu \mathrm{m}\right.$ porosity), which was maintained at a temperature of $-20{ }^{\circ} \mathrm{C}$ until the time of analysis.

\subsection{Determination of Extracellular Xylanase Activity}

The enzymatic activity was determined using the modified method of Schinner and Von Mersi (1990), which was used to evaluate the activity of xylanases in soil extracts. According to the original method, the reducing sugars formed during the incubation of extracts in the presence of xylan $(1.2 \%$ in $2 \mathrm{M}$ acetate buffer, $\mathrm{pH} 5.5)$ at $50{ }^{\circ} \mathrm{C}$ for $24 \mathrm{~h}$ were quantified colorimetrically after reaction with ferric potassium hexacyane under specific conditions, using glucose as the standard. In this study, the incubation period was reduced from $24 \mathrm{~h}$ to $1 \mathrm{~h}$; other conditions were the same as in the original method. A low protein content of the cell extracts under the conditions used for the culture of bacteria was reported. Therefore, this method was chosen instead of the traditionally employed dinitrosalicylic acid method (Miller, 1959), since it has a sensitivity which is approximately 200 times higher for detection of reducing sugars (Schinner \& Von Mersi, 1990). For these analyses, $100-\mu \mathrm{L}$ aliquots of each EPE were added to $3 \mathrm{~mL}$ of acetate buffer and $3 \mathrm{~mL}$ of xylan buffer in test tubes, which were incubated at $50{ }^{\circ} \mathrm{C}$ for $1 \mathrm{~h}$ in triplicate. For the controls, EPE addition took place after the incubation period. For quantification of the reducing sugars, $100-\mu \mathrm{L}$ aliquots were pipetted into test tubes and the volume made up to $1 \mathrm{~mL}$ with distilled water; $1 \mathrm{~mL}$ of reagent $\mathrm{A}\left(16 \mathrm{~g} \mathrm{~L}^{-1}\right.$ of anhydrous sodium carbonate and $0.9 \mathrm{~g} \mathrm{~L}^{-1}$ of potassium cyanide) and $1 \mathrm{~mL}$ of reagent $\mathrm{B}\left(0.5 \mathrm{~g} \mathrm{~L}^{-1}\right.$ of ferric hexacyane potassium) were then added. The test tubes were sealed and placed in a water bath at $100^{\circ} \mathrm{C}$ for $15 \mathrm{~min}$. After this period, the contents of the tubes were cooled rapidly in a cold water bath for approximately $5 \mathrm{~min}$ and $5 \mathrm{~mL}$ of reagent $\mathrm{C}\left(1.5 \mathrm{~g} \mathrm{~L}^{-1}\right.$ ferric ammonium sulfate, $1.0 \mathrm{~g} \mathrm{~L}^{-1}$ of sodium dodecyl sulfate and $4.2 \mathrm{~mL}$ of $\mathrm{L}^{-1}$ of concentrated sulfuric acid) was then added. After color stabilization for $1 \mathrm{~h}$ at room temperature, the absorption was measured at $690 \mathrm{~nm}$ to determine the formation of reducing sugars. A reducing sugar standard curve based on glucose ( 0 to $18 \mu \mathrm{g}$ glucose $\left.\mathrm{mL}^{-1}\right)$ was used to convert the absorbance into the amount of product formed by the reaction. Reactions for the detection of reducing sugars were performed in duplicate.

The total protein content in these extracts was determined by the method of Bradford (1976) as recommended by the supplier for the detection of proteins in the range of 8 to $80 \mu \mathrm{g} \mathrm{mL}^{-1}$ (Bio-Rad). Bovine serum albumin (BSA) solutions with known concentrations were used as the standard. 
The specific activity of the extracellular xylanases was determined by the ratio between the rate of formation of reducing sugars and the concentration of total proteins in the EPE. The units were expressed as $\mu \mathrm{g}$ of reductive sugar $\mathrm{min}^{-1} \mathrm{mg}^{-1}$ protein.

\subsection{Enzyme Characterization}

The three isolates with the highest specific activity in the previous assay were selected for the determination of the optimum temperature of activity and thermostability of the xylanases. Quantification of the activity in the two determinations was performed using the method of Schinner and Von Mersi (1990) in the same manner as previously described. For the optimum temperature of activity test, the incubation of the protein extracts was carried out at temperatures ranging from 30 to $80^{\circ} \mathrm{C}$, with increments of $10^{\circ} \mathrm{C}$. The results were presented as relative activity, expressed as the percentage of specific activity at each temperature in relation to the maximum specific activity observed at the six incubation temperatures. For determination of the enzymatic stability at temperature, $100 \mu \mathrm{L}$ of extract was added to test tubes containing $3 \mathrm{~mL}$ of acetate buffer without xylan and incubated for 2,4 and $6 \mathrm{~h}$ at $60{ }^{\circ} \mathrm{C}$. After each of these incubation periods, $3 \mathrm{~mL}$ of acetate buffer with xylan $(1.2 \%)$ was added to the contents of the vials and the incubation was carried out to determine the residual activity of xylanases at $50^{\circ} \mathrm{C}$ for $1 \mathrm{~h}$. Determination of the reducing sugars formed was performed as previously described. The specific activity of xylanases at $50{ }^{\circ} \mathrm{C}$, without pre-incubation at $60{ }^{\circ} \mathrm{C}$, was used as the control, and the activities after 2, 4 and $6 \mathrm{~h}$ of pre-incubation were expressed as a percentage of the control value.

The three isolates selected were also tested for xylanase stability at $\mathrm{pH}$ values of 4.0, 5.5 and 8.0. To this end, $250 \mu \mathrm{L}$ of each extract was incubated for $24 \mathrm{~h}$ at $4{ }^{\circ} \mathrm{C}$ in $750 \mu \mathrm{L}$ of McIlvaine buffer (Mcllvaine, 1921) adjusted to each $\mathrm{pH}$ value. After this period, $100-\mu \mathrm{L}$ aliquots were incubated at $50{ }^{\circ} \mathrm{C}$ in $3 \mathrm{~mL}$ of acetate buffer and $3 \mathrm{~mL}$ of acetate buffer with xylan $(1.2 \%)$ for $1 \mathrm{~h}$ and the reducing sugar content formed by the residual activity of the xylanases quantified as previously described. For the background solution, $100-\mu \mathrm{L}$ aliquots of the pre-incubated EPEs with different $\mathrm{pH}$ values were added immediately before the reactions for the determination of reducing sugars. The maximum residual specific activity among the three $\mathrm{pH}$ values tested was used as reference and the results expressed as relative activity (percentage of the reference activity).

\subsection{Determination of Cellulase Activity}

For the isolate with the highest xylanase specific activity, cellulase activity was determined in the protein extract obtained after incubation in medium containing xylan as the sole carbon source. This activity was determined by the method of Schinner and von Mersi (1990), replacing xylan with disodium CM-cellulose $\left(7 \mathrm{~g} \mathrm{~L}^{-1}\right.$ of $2 \mathrm{M}$ acetate buffer, $\mathrm{pH} 5.5$ ). The procedures for reading the samples and the standard curve followed the methodology described in the previous sections.

\section{Results and Discussion}

From 120 isolates evaluated, 114 (95\% of the total) presented growth in medium with xylan as the only carbon source. Despite this high frequency, only 22 isolates ( $25 \%$ of the total) showed xylanase activity, detected by the formation of pale halos around the colonies under the conditions tested (Table 1). This discrepancy may be associated with free glucose and arabinose contamination in the beechwood xylan used, which would act as a carbon source and allow initial growth of the colonies without xylanase activity. Although 50 bacteria from the collection were isolated in VL55 medium, which has several nutritional factors, especially vitamins, most of these bacteria are metabolically versatile in nutritional terms, displaying growth in MSS medium whose composition has only mineral salts and xilan as a source of carbon. From 22 bacteria that showed halo xylanase activity under the conditions tested, 20 showed growth at up to seven days of incubation and only two (TC14C and TC9D) between seven and 14 days. As for the date of detection of xylanase activity, all bacteria, except TC97, presented halos on the first date that activity was evaluated (Figure 1a). High variability among isolates was observed in xylanase expression capacity under the conditions tested, regardless of the dates of evaluation of enzyme activity (Figure 1). In the first evaluation date the $\mathrm{H}: \mathrm{C}$ ratio ranged from 1.44 to 4.26 , between TC89 and TC21 isolates, respectively. This variation corresponded to 3.7 times the standard deviation (SD) observed among the isolates of the collection and a $290 \%$ increase among the isolates of the minimum and maximum $\mathrm{H}: \mathrm{C}$ value. For the second evaluation date, the H:C values ranged from 1.44 to 4.73 for TC89 and TC92 (Figure 1b), which corresponded to 3.4 times the SD between isolates and a $230 \%$ increase between the isolates of the minimum and maximum $\mathrm{H}: \mathrm{C}$ value. 
Table 1. Characterization of bacterial isolates with xylanase halos formation activity for taxonomic affiliation based on 16r DNAr, culture rarity, soil type and techniques used in isolation

\begin{tabular}{|c|c|c|c|c|c|c|c|c|c|c|}
\hline Strains & Phylum & Family $^{1}$ & $\begin{array}{l}\text { Species with maximum } \\
\text { similarity at } 16 \mathrm{~S} \text { DNAr }\end{array}$ & $\begin{array}{l}\text { Culture } \\
\text { rarity }^{2}\end{array}$ & $\begin{array}{l}\text { Soil } \\
\text { type }^{3}\end{array}$ & $\begin{array}{l}\text { Inoculum } \\
\text { dilution }^{4}\end{array}$ & $\begin{array}{l}\text { Culture } \\
\text { media }^{5}\end{array}$ & $\begin{array}{l}\text { Solidifying } \\
\text { agent }\end{array}$ & $\begin{array}{l}\text { Plating } \\
\text { technique }^{6}\end{array}$ & $\begin{array}{l}\text { Colony } \\
\text { formation } \\
\text { (days) }\end{array}$ \\
\hline TC10C & Acidobacteria & Acidobacteriaceae & $\begin{array}{l}\text { Edaphobacter aggregans } \\
(98 \%)\end{array}$ & Commom & FS & D6 & VL & Gellan & $\mathrm{PE}$ & 7 \\
\hline TC13B & Actinobacteria & Micromonosporaceae & Micromonospora sp. (98\%) & Commom & FS & D6 & AN & Gellan & $\mathrm{PE}$ & 4 \\
\hline TC49 & Actinobacteria & "Micrococcaceae" & Arthrobacter sp. $(99 \%)$ & Rare & FS & D6 & AN1:10 & Gellan & PP & 4 \\
\hline TC6B & Actinobacteria & Streptomycetaceae & $\begin{array}{l}\text { Streptomyces djakartensis } \\
(98 \%)\end{array}$ & Commom & FS & D6 & AN & Agar & PE & 7 \\
\hline TC79 & Actinobacteria & Streptomycetaceae & $\begin{array}{l}\text { Streptomyces albospinus } \\
(98 \%)\end{array}$ & Commom & FS & D6 & AN & Agar & $\mathrm{PE}$ & 4 \\
\hline TC9D & Actinobacteria & "Micromonosporaceae" & Planosporangium sp. (93\%) & Rare & FS & D6 & VL & Agar & $\mathrm{PE}$ & 21 \\
\hline TC106 & Firmicutes & Bacillaceae & Bacillus sp. (99\%) & Commom & FS & D6 & AN1:100 & Agar & $\mathrm{PE}$ & 7 \\
\hline TC123 & Firmicutes & "Bacillaceae" & Bacillus sp. (99\%) & Rare & FS & D6 & VL & Gellan & PP & 7 \\
\hline TC38 & Firmicutes & Bacillaceae & Bacillus subtilis (99\%) & Commom & FS & D7 & AN1:10 & Gellan & PP & 14 \\
\hline TC67 & Firmicutes & Bacillaceae & Bacillus subtilis $(96 \%)$ & Commom & FS & D7 & $\mathrm{AN}$ & Agar & PP & 7 \\
\hline TC72 & Firmicutes & "Bacillaceae" & Bacillus cereus $(98 \%)$ & Rare & AS & D6 & AN1:10 & Gellan & $\mathrm{PE}$ & 4 \\
\hline TC83 & Firmicutes & Bacillaceae & Bacillus subtilis $(99 \%)$ & Commom & AS & D6 & AN1:100 & Agar & PP & 7 \\
\hline TC89 & Firmicutes & Bacillaceae & Bacillus safensis $(99 \%)$ & Commom & AS & D6 & AN1:100 & Agar & PP & 4 \\
\hline TC119 & Proteobacteria & "Methylobacteriaceae" & Methylobacterium sp. (99\%) & Rare & AS & D6 & VL & Gellan & PP & 4 \\
\hline TC137 & Proteobacteria & Bradyrhizobiaceae & Bradyrhizobium sp. (99\%) & Commom & AS & D7 & VL & Agar & $\mathrm{PE}$ & 63 \\
\hline TC14C & Proteobacteria & Caulobacteraceae & Phenylobacterium sp. (97\%) & Commom & FS & D7 & VL & Gellan & $\mathrm{PE}$ & 21 \\
\hline $\mathrm{TC} 21$ & Proteobacteria & "Phyllobacteriaceae" & Mesorhizobium sp. (97\%) & Rare & FS & D6 & VL & Gellan & PP & 14 \\
\hline TC66 & Proteobacteria & Burkholderiaceae & Ralstonia pickettii (95\%) & Commom & FS & D6 & VL & Gellan & $\mathrm{PE}$ & 14 \\
\hline TC88 & Proteobacteria & "Rhizobiaceae" & $\begin{array}{l}\text { Rhizobium miluonense } \\
(96 \%)\end{array}$ & Rare & AS & D7 & AN & Agar & PP & 7 \\
\hline TC92 & Proteobacteria & "Phyllobacteriaceae" & $\begin{array}{l}\text { Phyllobacterium trifolii } \\
(95 \%)\end{array}$ & Rare & AS & D7 & AN & Gellan & PP & 4 \\
\hline TC97 & Proteobacteria & Methylobacteriaceae & $\begin{array}{l}\text { Methylobacterium isbiliense } \\
(94 \%)\end{array}$ & Commom & AS & D6 & AN & Gellan & $\mathrm{PE}$ & 4 \\
\hline TC99 & Proteobacteria & Ralstoniaceae & Ralstonia sp. (99\%) & Commom & $\mathrm{FF}$ & D7 & AN1:10 & Gellan & $\mathrm{PE}$ & 28 \\
\hline
\end{tabular}

Note. ${ }^{1}$ Quoted names indicate families with which the isolates had the highest similarity in the 16S rDNA sequence, although they did not affiliate with them; ${ }^{2}$ According to the methodology of Joseph et al. $(2003) ;{ }^{3} \mathrm{FS}$ : soil under secondary forest; AS: only under agricultural cultivation; ${ }^{4}$ Plating of $100 \mu \mathrm{l}$ of dilution 10-6 (D6) and 10-7 (D7); ${ }^{5}$ VL: VL55 (Sait et al., 2002); AN, AN1: 10 and AN1: 100: nutrient agar without dilution, diluted 10 and 100 fold, respectively; ${ }^{6}$ PP: "pour-plate", PE: spread plate.

The sequence of isolates with regard to the $\mathrm{H}: \mathrm{C}$ ratio differed between the first and second evaluation dates (Figure 1). Several studies have previously observed late gene expression in bacterial isolates, such as studies with nodC and nodW nodulation genes and the nopP gene in Bradyrhizobium japonicum, which probably act on the infection of soybean roots (Bortolan, Barcellos, Marcelino, \& Hungria, 2009), or expression of GDH gene in Lactobacillus plantarum DPPMA49 in response to different environmental conditions (De Angelis et al., 2010), which revealed differences in the activation of the gene expression machinery in response to the medium.

These changes were characterized by halo formation by TC97 only on the second evaluation date and by the increase in the $\mathrm{H}: \mathrm{C}$ ratio between the two dates for some bacteria, especially TC119, TC66, TC92, TC13B and TC99. The gap between colony formation and expression of xylanase activity may be related to mechanisms of catabolic repression, in which sugars of more easy assimilation represses the expression of genes involved in the use of polymers of more complex structure, as already demonstrated with the fungus Trichoderma reesei (Mach, Strauss, Zeilinger, Schindler, \& Kubicek, 1996) and on Bacillus stearothermophilus and Bacillus subtilis (Cho \& Choi, 1999). 

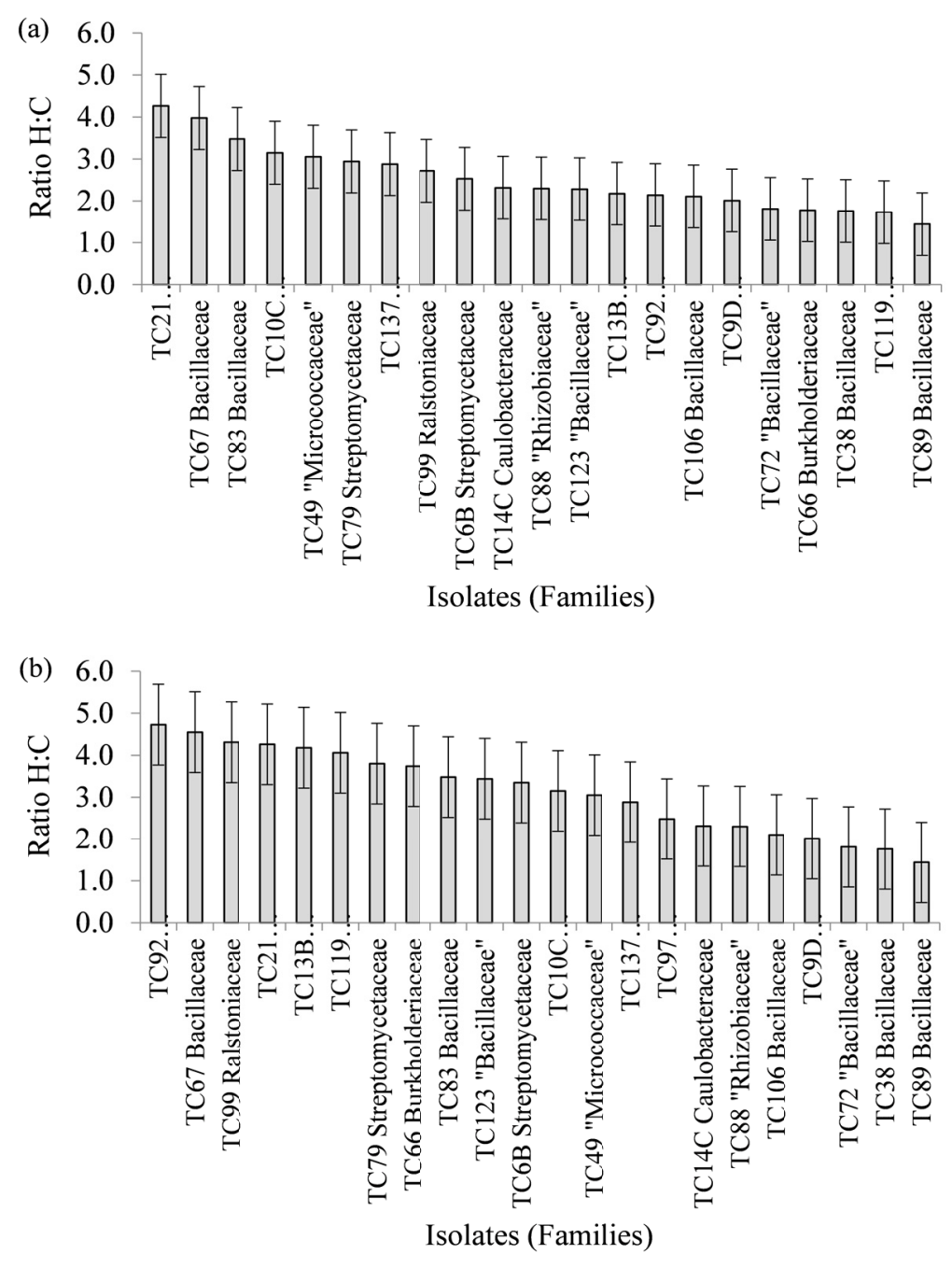

Figure 1. Activity of xylanase from bacteria isolates expressed as the ratio between the halo diameters of enzyme activity and bacterial colony ( $\mathrm{H}: \mathrm{C}$ ratio) in mineral saline medium with xylan as sole carbon source. For each isolate the $\mathrm{H}$ : $\mathrm{C}$ ratio was evaluated at 0 days (a) and at 7 days (b) after observation of colony growth. For details on the identification of the isolates, see Table 1. Quoted names indicate families with which the isolates showed the highest similarity in the $16 \mathrm{~S}$ rDNA sequence, although they do not affiliate with them. The error bars represent \pm 1 D.P. of the mean of $\mathrm{H}$ : $\mathrm{C}$ among all the isolates

No relationship was observed between efficiency of xylanase activity and the taxonomic affiliation of isolates in terms of phyla or families (Figure 1). Based on the partial sequences of 16r rDNA, these isolates belong to six distinct phyla whose percentage contribution in terms of representatives in the collection decreased in the following order: Actinobacteria (35\%), Firmicutes (34\%), Proteobacteria (28\%), Acidobacteria, Chloroflexi and Deinococcus-Thermus (less than 1\% each) (Cavalcante, 2012). The phylogenetic analysis of this sequence, following the methodology used by Joseph, Hugenholtz, Sangwan, Osborne, and Janssen (2003), indicated that 42 isolates (34\%) were classified as rare isolates, because they belong to groups with a hierarchical level equivalent to a family without cultivated representatives until now. With respect to xylanolytic activity, in terms of the number of representatives per family, a dominance of Bacillaceae isolates was observed in the tested condition ( $23 \%$ of the isolates). This observation is in line with this family being the most extensively studied and reported with regard to the potential for xylanases production (Kamble \& Jadhav, 2012). In addition, two representatives of rare isolates, TC123 and TC72, belonging to the Firmicutes phylum, showed xylanase activity.

As for the number of representatives per phylum, a high frequency of Proteobacteria (43\%), especially Alphaproteobacteria (33\%), with xylanolytic activity was observed. It is widely reported that representatives of this phylum are xylanase producers (Mohana et al., 2008; Wang et al., 2010). Isolates of the families 
Phyllobacteriaceae, Bradyrhizobiaceae, Caulobacteriaceae, Rhizobiaceae and Methylobacteriaceae, besides four representatives of rare isolates of Alphaproteobacteria, and Ralstoniaceae and Burkholderiaceae (Betaproteobacteria class) were observed.

Xylanolytic isolates of the phylum Actinobacteria also presented high frequency (25\%), with isolates identified from the families Micrococcaceae, Streptomycetaceae and Micromonosporaceae. There are several studies on the enzymatic degradation of xylan in this phylum, especially of the genus Streptomyces, such as Streptomyces matensis DW67 (Yan, Hao, Jiang, Zhai, \& Chen, 2009) and Streptomyces rameus L2001 (Li et al., 2012a). The isolate TC10C (Acidobacteria) was one of the most active xylanolytics in solid test conditions. Although it is considered a phylum that is difficult to cultivate, the activity of xylanases in the periplasmic space of Acidobacterium capsulatum, also belonging to this phylum, has been previously reported (Inagaki, Nakahira, Mukai, Tamura, \& Tanaka, 1998).

None of the variations in isolation methods nor differences among isolates as to the rarity of isolation condition (Table 1) affected the efficiency of xylanase activity assessed by the $\mathrm{H}: \mathrm{C}$ ratio under the conditions tested (Figure 2). It is interesting to note that although the VL55 medium (Sait et al., 2002), used by Cavalcante (2012) to obtain this collection, contained only xylan as a carbon source, it did not produce a better performance in terms of isolates with higher xylanase activity than the original or 10- or 100-fold diluted nutrient agar.

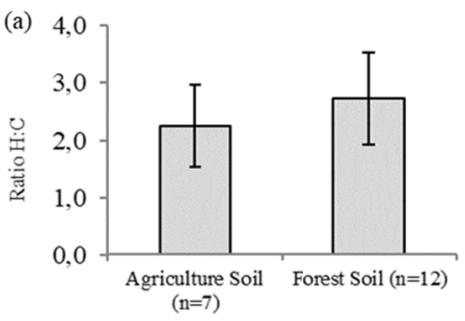

Soil type

(d)

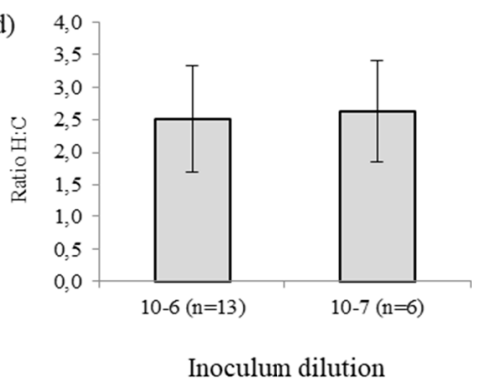

(b)

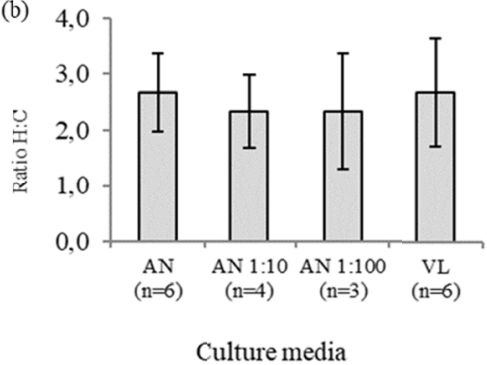

(e)
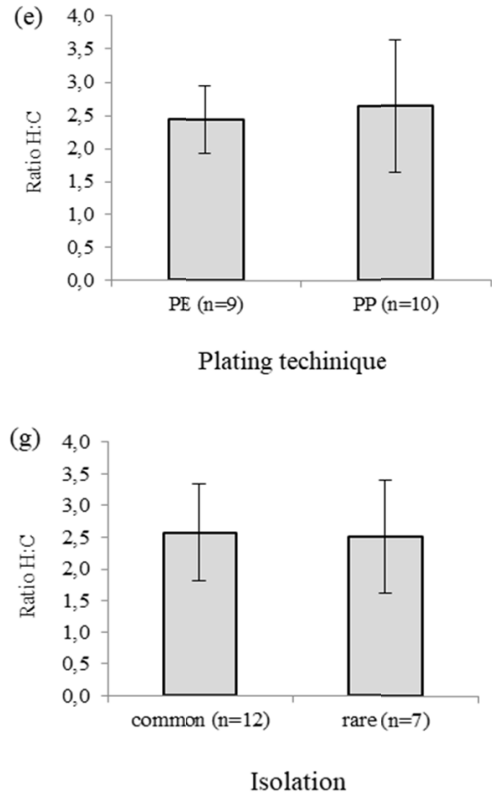

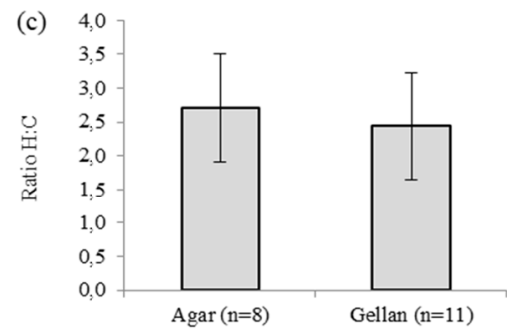

Solidifying agent

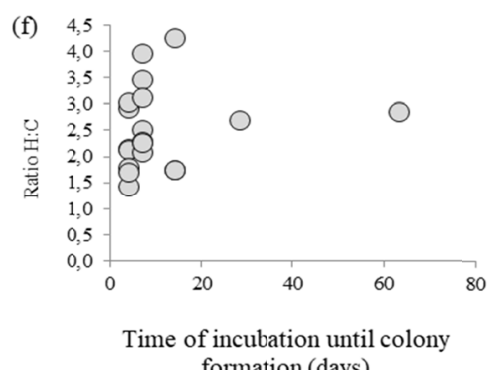

formation (days)

Figure 2. Comparisons of the xylanase activity and halo diameters (H: $\mathrm{C}$ ratio) relationships of bacteria according to source soils (a), culture media (b), solidifying agents (c); dilutions of the inoculum (d), plating technique (e) and incubation time ( $\mathrm{f}$ ) used in isolation, and the rarity of cultivation ( $\mathrm{g}$ ). Values of $\mathrm{n}$ indicate the number of isolates included in each of the factor classes compared. Means differences between the comparative

classes were not significant $(p>0.05)$ or were not observed for any of the factors analyzed. To identify the isolates included in each class of factors, see Table 1. Only isolates with halos formed on the first evaluation date of xylanase activity were included in the analyzes 
Eleven isolates that presented the highest $\mathrm{H}: \mathrm{C}$ ratios were tested for the activity of xylanases in the extracellular proteic extract (EPE). Of these, nine presented activity under the conditions evaluated (Figure 3). The loss of xylanase activity in EPE compared with solid media activity, from the TC83 and TC10C, may be associated with the low stability of these enzymes under the temperature conditions of this test $\left(50^{\circ} \mathrm{C}\right)$ compared to the plaque $\left(30^{\circ} \mathrm{C}\right)$ method. In addition, the shorter incubation period of the enzymes in the presence of xylan $(1 \mathrm{~h})$, compared to that used for testing in solid medium with the bacteria (up to 14 days), may have limited the detection of enzyme activity.

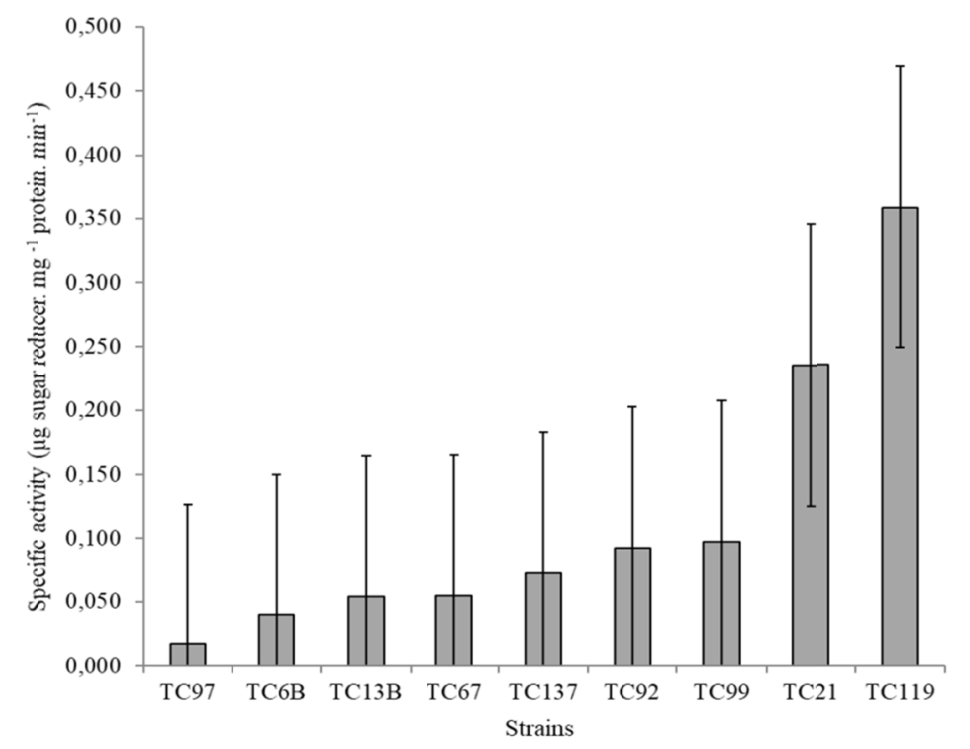

Figure 3. Specific activity of xylanases in crude extracts of nine soil bacterial isolates, in activity reaction with incubation at $50{ }^{\circ} \mathrm{C}$. Error bars correspond to $\pm 1 \mathrm{SD}$ of the mean of specific activity of all these isolates. For details of the isolate codes, see Table 1

As observed with the $\mathrm{H}: \mathrm{C}$ ratio, a high variability in the specific xylanase activity of EPE at $50{ }^{\circ} \mathrm{C}$ was found

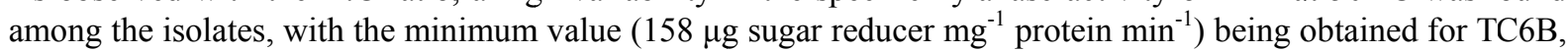
with high similarity to Streptomyces djakartensis, and the highest $\left(2565 \mu \mathrm{g}\right.$ sugar reducer $\mathrm{mg}^{-1}$ protein $\left.\mathrm{min}^{-1}\right)$ for a rare isolate TC119, belonging to the class Alphaproteobacteria (Figure 3). Although species of Bacillus and Streptomyces are reported to be the main sources of xylanases for commercial use, only one isolate of each of these genera (TC67 and TC6B) was obtained among those with high xylanase activity in the EPE under the conditions tested. Interestingly, the specific activity of these two isolates corresponded to only 6 to $10 \%$ of that obtained for the three most efficient isolates (TC119, TC99 and TC21) in this study. It is emphasized that 18 isolates of Bacillus and 10 of Streptomyces were tested in this study. In addition, another Actinobacteria, TC13B, affiliated with the family Micromonosporaceae, presented a $650 \%$ greater activity than that observed by Streptomyces TC6B.

Among the three best isolates, two, TC119 and TC21, belong to groups that are hierarchically equivalent to families for which cultured representatives were not previously known (Cavalcante, 2012). These isolates affiliated more closely to the families Methylobacteriaceae and Phyllobacteriaceae, respectively, both Alphaproteobacteria. Although TC119 is not affiliated with Methylobacteriaceae, this isolate shows growth capacity in methanol as the only source of carbon, a typical characteristic of representatives of this family.

The three isolates with the highest xylanase activity in the EPE had very different temperature response profiles (Figure 4). TC99, affiliated with Ralstoniaceae, had an optimal xylanase activity temperature at $40{ }^{\circ} \mathrm{C}$, with a marked decrease above this temperature (Figure 4a). Although TC119 also showed an optimum activity at this same temperature, EPE activity remained relatively high (about $60 \%$ of the maximum) at up to $70{ }^{\circ} \mathrm{C}$, with a sharp drop being observed above this temperature. The temperature optimum for TC 21 xylanase activity was $60{ }^{\circ} \mathrm{C}$, with a marked drop above this temperature. However, the xylanases of this isolate still showed about $35 \%$ activity after incubation at $80^{\circ} \mathrm{C}$ for $1 \mathrm{~h}$. Studies report that Bacillus spp. are microorganisms that are known to 
produce high levels of xylanase activity at alkaline $\mathrm{pH}$ and high temperature (Subramaniyan, Sandhia, \& Prema, 2001).
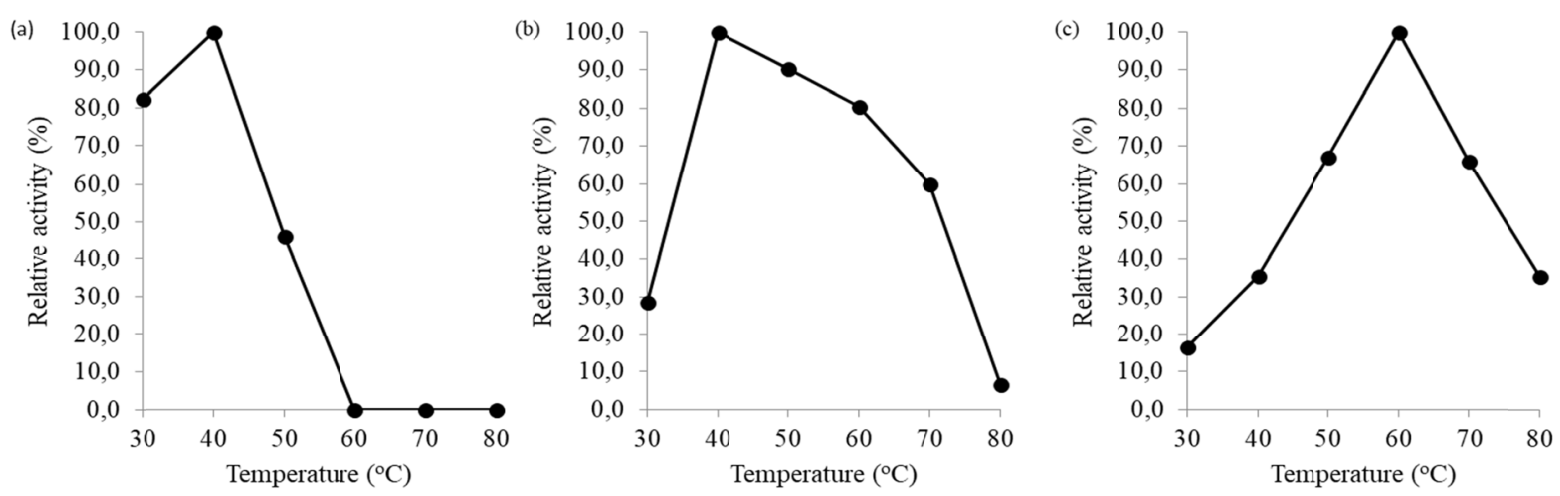

Figure 4. Reactions of the relative activities of xylanases in crude extracts of TC99 (a), TC119 (b) and TC21 (c) isolates at incubation temperatures during the reaction. For each isolate the maximum reaction activity was considered as $100 \%$

The xylanases of the TC21 EPE were still highly stable at $60{ }^{\circ} \mathrm{C}$, with a decrease of only $20 \%$ in the activity after $6 \mathrm{~h}$ of incubation (Figure 5). On the other hand, TC119 xylanases were less thermostable, with reductions of 55\% in activity after $2 \mathrm{~h}$ of incubation at $60^{\circ} \mathrm{C}$.

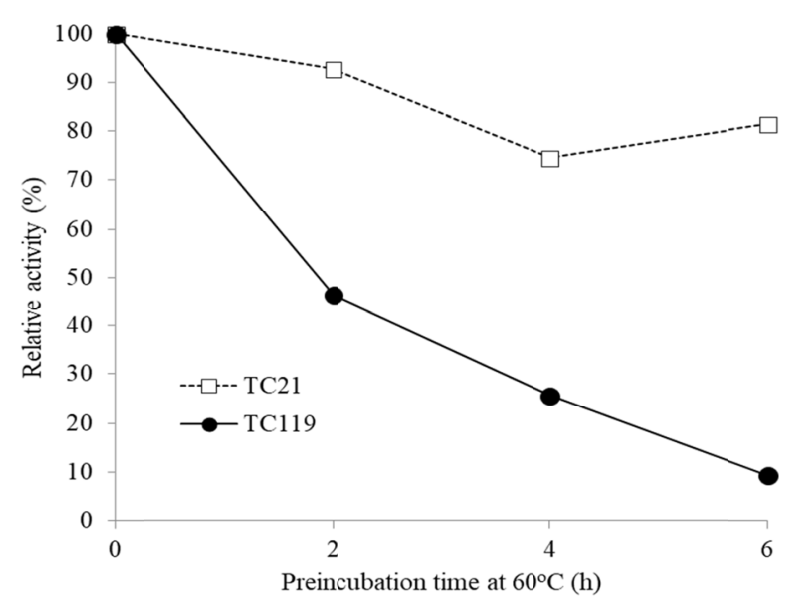

Figure 5. Stability of the xylanase activity of the crude extract of the TC21 and TC119 isolates as a function of the preincubation time at $60{ }^{\circ} \mathrm{C}$

Regarding pH stability, the xylanase activity response profiles also differed among the three isolates (Figure 6). TC99 was sensitive to both the more acidic $(\mathrm{pH} \mathrm{4.0)}$ and the more alkaline conditions ( $\mathrm{pH} \mathrm{8.0).} \mathrm{On} \mathrm{the} \mathrm{other}$ hand, TC119 and TC21 were highly stable at the different $\mathrm{pH}$ values investigated. In both cases, in comparison to the optimum $\mathrm{pH}(5.5)$, changes were not observed at $\mathrm{pH} 4.0$, and reductions under $\mathrm{pH} 8.0$ were less pronounced $(<25 \%$ decrease) after $24 \mathrm{~h}$ of incubation. 

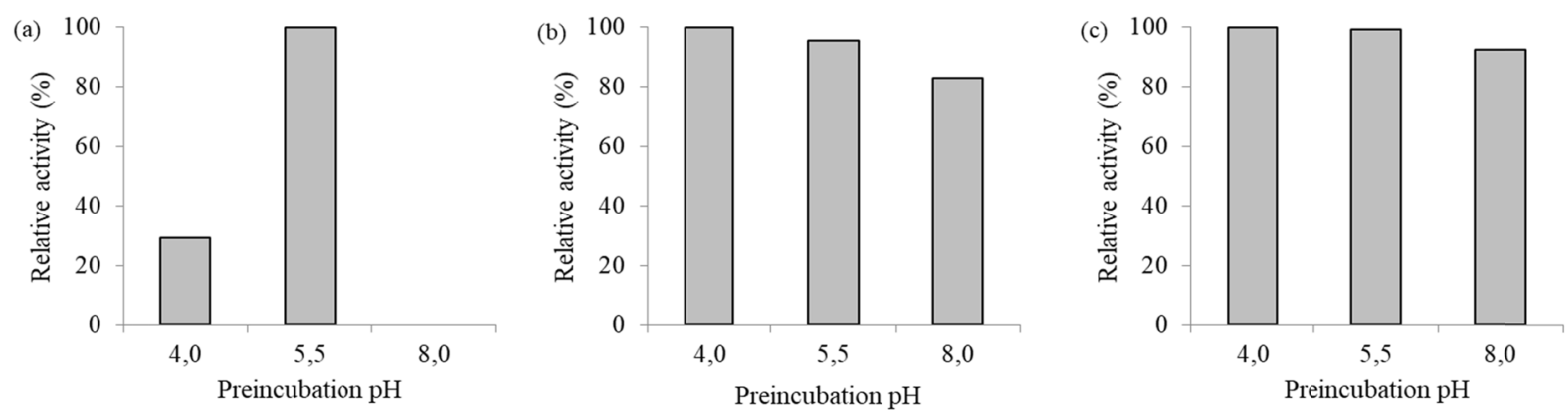

Figure 6. Stability of the xylanase activity of the TC99 (a), TC119 (b) and TC21 (c) isolates of the crude extract as a function of pre-incubation at $\mathrm{pHs} 4.0,5.5$ and 8.0 for 24 ha $4{ }^{\circ} \mathrm{C}$

In the process of bleaching wood pulp in the cellulose industry, the enzymatic step requires the use of enzymes with high stability at elevated temperatures and $\mathrm{pH}$ (Gomes, Guez, Martin, \& Silva, 2007). Temperature values of $70{ }^{\circ} \mathrm{C}$ and $\mathrm{pH} 9.0$ are commonly found in these processes (Techapun et al., 2003). Thus, isolate TC99 has low potential for this purpose. State-of-the-art enzymes in the market for wood pulp bleaching have shown high activity at temperatures up to $90{ }^{\circ} \mathrm{C}$ and $\mathrm{pH}$ up to 9.0 , and periods of 20 min for completion of reactions, according to the manufacturer (Verenium Corporation, San Diego, CA). Xylanases from the TC119 and TC21 EPE have activity and temperature profiles similar to or higher than the Luminase ${ }^{\circledR}$-PB100 trade mark of one of these enzymes (endo-1,4- $\beta$-glucanase; EC 3.2.1.4), which has an activity range of 40 to $70{ }^{\circ} \mathrm{C}$ and $\mathrm{pH} 5.0$ to 8.0.

In addition to the high activity potential of TC119 xylanases at the temperature and $\mathrm{pH}$ conditions of the pulp bleaching process, these enzymes showed no cellulase activity when incubated in the presence of carboxymethyl cellulase after $1 \mathrm{~h}$ of incubation at $50{ }^{\circ} \mathrm{C}$. The absence of cellulase activity in xylanases is a feature of great importance for the paper industry, since this activity can compromise the structure of the cellulosic fibers (Christov, Szakacs, \& Balakrishnan, 1999).

During the production of second generation ethanol, the optimum $\mathrm{pH}$ used in the fermentation phase may vary due to the different fermentation media used, growing conditions or even different strains, and it is important to determine the best $\mathrm{pH}$ range for a given fermentation process (Du Preez, 1994). Studies have reported the decrease of $\mathrm{pH}$ of the medium as a function of this process in several organisms (Narendranath \& Power, 2005). In addition, temperatures around $55^{\circ} \mathrm{C}$ are commonly attained (Olofsson, Bertilsson, \& Lidén, 2008). Thus, the enzymes of TC119 and TC21 also present potential for use in these processes, since they showed high activity in these conditions.

Although very important characteristics for the industrial use of xylanases have been found in the extracellular extracts of some evaluated isolates, further research steps are needed to enable biotechnological use of these xylanases. These steps include the separation, molecular characterization and confirmation of the activity and stability at temperature and $\mathrm{pH}$ of each of the enzymes components of the xylanolytic complex of EPE, optimization of the conditions for production of these enzymes by the bacteria in fermentation in the solid and submerged state, and determination of the structures, amplification and cloning of related genes.

\section{Conclusion}

Putting together our data, we can conclude that soil bacteria present high variability in their ability to hydrolyze xylan, but this variability is not associated with isolation factors or the rarity of cultivation of crops. However extracellular xylanases from isolates from bacterial families which have been poorly exploited for the production of these enzymes (e.g. Methylobacteriaceae, Phyllobacteriaceae, Micromonosporaceae and Bradyrhizobiaceae) are more active under the conditions tested than those of representatives of the genera Bacillus and Streptomyces present in the evaluated collection. Some rare isolates (TC119 and TC21), not affiliated with bacterial families already described, stand out among the bacteria in the collection with regard to the high relative activity of extracellular xylanases at temperatures up to $70{ }^{\circ} \mathrm{C}$ and at $\mathrm{pH}$ values in the range 4.0 to 8.0. Extracellular xylanases from TC119 do not show cellulolytic activity.

Bacteria which have been rarely isolated from soil present high potential as sources of extracellular xylanases adapted to the extreme conditions of $\mathrm{pH}$ and temperature required in agro-industrial processes. 


\section{Acknowledgements}

The authors thank CAPES (Coordination for the Improvement of Higher Education Personnel) and CNPQ (National Council for Scientific and Technological Development) for the scholarships. This study was supported by Fapitec-SE and Capes.

\section{References}

Achtman, M., \& Wagner, M. (2008). Microbial diversity and the genetic nature of microbial species. Nature Reviews Microbiology, 6, 431-440. https://doi.org/10.1038/nrmicro1872

Bajaj, B. K., \& Singh, N. P. (2010). Production of xylanase from an alkalitolerant Streptomyces sp. $7 \mathrm{~b}$ under solid-state fermentation, its purification and characterization. Applied Biochemistry and Biotechnology, 162, 1804-1818. https://doi.org/10.1007/s12010-010-8960-X

Bon, E. P. S., Ferrara, M. A., \& Corvo, M. L. (2008). Enzimas em biotecnologia-Produção, aplicações e mercado. Rio de Janeiro, RJ: Editora Interciência.

Bortolan, S., Barcellos, F. G., Marcelino, F. C., \& Hungria, M. (2009). Expressão dos genes nodC, nodW e nopP em Bradyrhizobium japonicum estirpe CPAC 15 avaliada por RT-qPCR. Pesquisa Agropecuária Brasileira, 44, 1491-1498, 2009. https://doi.org/10.1590/S0100-204X2009001100017

Bradford, M. M. (1976). A rapid and sensitive method for the quantification of microgram quantities of protein utilizing the principle of protein-dye binding. Analytical Biochemistry, 76, 248-254. https://oi.org/10.1006/ abio.1976.9999

Canilha, L., Chandel, A., Milessi, T. S. D., Antunes, F., Freitas, W., Felipe, M. D. A., \& Da Silva, S. S. (2012). Bioconversion of Sugarcane Biomass into Ethanol: An Overview about Composition, Pretreatment Methods, Detoxification of Hydrolysates, Enzymatic Saccharification, and Ethanol Fermentation. Journal of Biomedicine and Biotechnology, 2012. https://doi.org/10.1155/2012/989572

Cavalcante, A. C. S. (2012). Ampliação da diversidade de bactérias cultiváveis do solo pelo uso de técnicas simples de cultivo (Unpublished master's thesis, Universidade Federal de Sergipe, Sergipe, Brazil).

Chakdar, H., Kumar, M., Pandiyan, K., Singh, A., Nanjappan, K., Kashyap, P. L., \& Srivastava, A. K. (2016). Bacterial xylanases: Biology to biotechnology. 3 Biotech, 6(150). https://doi.org/10.1007/s13205-0160457-z

Cho, S. G., \& Choi, Y. J. (1999). Catabolite repression of the xylanase gene (xynA) expression in Bacillus stearothermophilus no. 236 and B. subtilis. Bioscience, Biotechnology and Biochemistry, 63, $2053-2058$. https://doi.org/10.1271/bbb.63.2053

Christov, L. P., Szakacs, G., \& Balakrishnan, H. (1999). Production, partial characterization and use of fungal cellulase-free xylanases in pulp bleaching. Process Biochemistry, 34, 511-517. https://doi.org/10.1016/ S0032-9592(98)00117-4

Cowan, D. (1996). Industrial enzyme technology. Trends Biotechnology, 14, 177-178. https://doi.org/10.1016/ 0167-7799(96)30009-7

De Angelis, M., Calasso, M., Di Cagno, R., Siragusa, S., Minervini, F., \& Gobbetti, M. (2010), NADP-glutamate dehydrogenase activity in nonstarter lactic acid bacteria: Effects of temperature, $\mathrm{pH}$ and $\mathrm{NaCl}$ on enzyme activity and expression. Journal of Applied Microbiology, 109, 1763-1774. https://doi.org/10.1111/ j.1365-2672.2010.04804.x

Du Preez, J. C. (1994). Process parameters and environmental factors affecting D-xylose fermentation by yeasts. Enzyme and Microbial Technology, 16, 944-952. https://doi.org/10.1016/0141-0229(94)90003-5

BCC Research. (2014). Global markets for enzymes in industrial applications. Retrieved February 5, 2018, from http://www.bccresearch.com/pressroom/bio/global-market-industrial-enzymes-reach-nearly-\$7.1-billion.

Gomes, E., Guez, M. A. U., Martin, N., \& Silva, R. (2007). Enzimas termoestáveis: Fontes, produção e aplicação industrial. Química Nova, 30(1), 136-145. https://doi.org/10.1590/S0100-40422007000100025

Gurung, N., Ray, S., Bose, S., \& Rai, V. (2013). A broader view: Microbial enzymes and their relevance in industries, medicine, and beyond. BioMed Research International, 2013. https://doi.org/10.1155/2013/ 329121 
Haegeman, B., Hamelin, J., Moriarty, J., Neal, P., Dushoff, J., \& Weitz, J. S. (2013). Robust estimation of microbial diversity in theory and in practice. The ISME Journal, 7(6), 1092-1101. https://oi.org/10.1038/ ismej. 2013.10

Inagaki, K., Nakahira, K., Mukai, K., Tamura, T., \& Tanaka, H. (1998). Gene Cloning and Characterization of an Acidic Xylanase from Acidobacterium capsulatum. Bioscience, Biotechnology and Biochemistry, 62, 1061-1067. https://doi.org/10.1271/bbb.62.1061

Jayani, R. S., Shivalika, S., \& Gupta, R. (2005). Microbial pectinolytic enzymes: A review. Process Biochemistry, 40, 2931-2944. https://doi.org/10.1016/j.procbio.2005.03.026

Joseph, S. J., Hugenholtz, P., Sangwan, P., Osborne, C. A., \& Janssen, P. H. (2003). Laboratory cultivation of widespread and previously uncultured soil bacteria. Applied and Environmental Microbiology, 69, 7210-7215. https://doi.org/10.1128/AEM.69.12.7210-7215.2003

Kamble, R., \& Jadhav, A. R. (2012). Isolation, purification, and characterization of xylanase produced by a new species of Bacillus in solid state fermentation. International Journal of Microbiology, 2012, 1-8. https://doi.org/10.1155/2012/683193

Kashyap, D. R., Vohra, P. K., Chopra, S. E., \& Tewari, R. (2001). Applications of pectinases in the commercial setor: A review. Bioresource Technology, 77, 215-227. https://doi.org/10.1016/S0960-8524(00)00118-8

Li, X., Li, E., Zhu, Y., Teng, C., Sun, B., Song, H., \& Yang, R. (2012a). A typical endo-xylanase from Streptomyces rameus L2001 and its unique characteristics in xylooligosaccharide production. Carbohydrate Research, 359, 30-36. https://doi.org/10.1016/j.carres.2012.05.005

Li, S., Yang, X., Yang, S., Zhu, M., \& Wang, X. (2012b). Technology prospecting on enzymes: Application, marketing and engineering. Computational and Structural Biotechnology Journal, 2(3). https://doi.org/ 10.5936/csbj.201209017

Mach, R. L., Strauss, J., Zeilinger, S., Schindler, M., \& Kubicek, C. P. (1996). Carbon catabolite repression of xylanase I (xyn1) gene expression in Trichoderma reesei. Molecular Microbiology, 21(6), 1273-1281. https://doi.org/10.1046/j.1365-2958.1996.00094.x

McIlvaine, T. C. (1921). A buffer solution for colorimetric comparison. Journal of Biological Chemistry, 49, 183-186. https://doi.org/10.1093/nar/gkt1178

Miller, G. L. (1959). Use of dinitrosalicilic acid reagent for determination of reducing sugar. Analytical Chemistry, 31, 426-428. https://doi.org/10.1021/ac60147a030

Mohana, S., Shah, A., Divecha, J., \& Madamwar, D. (2008). Xylanase production by Burkholderia sp. DMAX strain under solid state fermentation using distillery spent wash. Bioresource Technology, 99, 16, 7553-7564. https://doi.org/10.1016/j.biortech.2008.02.009

Nagar, S., Mittal, A., Kumar, D., \& Gupta, V. K. (2012). Production of alkali tolerant cellulase free xylanase in high levels by Bacillus pumilus SV-205. International Journal of Biological Macromolecules, 50, 414-420. https://doi.org/10.1016/j.ijbiomac.2011.12.026

Narendranath, N. V., \& Power, R. (2005). Relationship between pH and Medium Dissolved Solids in Terms of Growth and Metabolism of Lactobacilli and Saccharomyces cerevisiae during Ethanol Production. Applied and Environmental Microbiology, 71(5), 2239-2243. https://doi.org/10.1128/AEM.71.5.2239-2243.2005

Niehaus, F., Bertoldo, C., Kahler, C., \& Antranikian, G. (1999). Extremophiles as a source of novel enzymes for industrial application. Applied Microbiology and Biotchenology, 51, 711-729. https://oi.org/10.1007/ s002530051456

Olofsson, K., Bertilsson, M., \& Lidén, G. (2008). A short review on SSF-An interesting process option for ethanol production from lignocellulosic feedstocks. Biotechnology for Biofuels, 1, 1-148. https://doi.org/ 10.1186/1754-6834-1-7

Pham, V. H. T., \& Kim, J. (2012). Cultivation of unculturable soil bacteria. Trends in Biotechnology, 30, $475-484$. https://doi.org/10.1016/j.tibtech.2012.05.007

Polizeli, M. L. T. M., Rizatti, A. C. S., Monti, R., Terenzi, H. F., Jorge, J. A., \& Amorim, D. S. (2005). Xylanase from fungi: Properties and industrial applications. Applied Microbiology and Biotechnology, 67(5), 577-591. https://doi.org/10.1007/s00253-005-1904-7 
Sait, M., Hugenholtz, P., \& Janssen, P. H. (2002). Cultivation of globally distributed soil bacteria from phylogenetic lineages previously only detected in cultivation-independent surveys. Environmental Microbiology, 4, 654-666. https://doi.org/10.1046/j.1462-2920.2002.00352.x

Schinner, F., \& Von Mersi, W. (1990). Xylanase, CM-celulase and invertase activity in soil: An improved method. Soil Biology and Biochemistry, 22(4), 511-515. https://doi.org/10.1016/0038-0717(90)90187-5

Schettino, M. A. S., \& Holanda, J. N. F. (2015). Processing of porcelain stoneware tile using sugarcane bagasse ash waste. Processing and Application of Ceramics, 9(1), 17-22. https://doi.org/10.2298/PAC1501017S

Sharma, P., \& Bajaj, B. K. (2005). Production and partial characterization of alkali-tolerant xylanase from na alkalophilic Streptomyces sp. CD3. Journal of Scientific \& Industrial Research, 64, 688-697.

Subramaniyan, S., Sandhia, G. S., \& Prema, P. (2001). Control of xylanase production without protease activity in Bacillus sp. by the selected nitrogen source. Biotechnology Letters, 23(5), 369-371. https://doi.org/ 10.1023/A:1005663704321

Techapun, C., Poosaram, N., \& Watanabe, M. (2003). Thermostable and alkaline-tolerant microbial cellulase-free xylanases produced from agricultural wastes and the properties required for use in pulp bleaching bioprocesses: A review. Process Biochemistry, 38, 1327-1340. https://doi.org/10.1016/ S0032-9592(02)00331-X

Walia, A., Guleria, S., Mehta, P., Chauhan, A., \& Parkash, J. (2017). Microbial xylanases and their industrial application in pulp and paper biobleaching: A review. 3 Biotech, 7(11). https://doi.org/10.1007/s12010010-8960-x

Wang, G., Wang, Y., Yang, P., Luo, H., Huang, H., Shi, P., .. Yao, B. (2010). Molecular detection and diversity of xylanase genes in alpine tundra soil. Applied Microbiology and Biotechnology, 87(4), 1383-1393. https://doi.org/10.1007/s00253-010-2564-9

Yan, Q., Hao, S., Jiang, Z., Zhai, Q., \& Chen, W. (2009). Properties of a xylanase from Streptomyces matensis being suitable for xylooligosaccharides production. Journal of Molecular Catalysis B: Enzymatic, 58, 72-77. https://doi.org/10.1016/j.molcatb.2008.11.010

\section{Copyrights}

Copyright for this article is retained by the author (s), with first publication rights granted to the journal.

This is an open-access article distributed under the terms and conditions of the Creative Commons Attribution license (http://creativecommons.org/licenses/by/4.0/). 